\title{
EHMTI-0124. Central vestibular system modulation in vestibular migraine - a VBM study
}

\author{
S Wurthmann ${ }^{1 *}$, S Naegel ${ }^{1}$, B Schulte Steinberg ${ }^{1}$, N Theysohn² ${ }^{2}$ HC Diener ${ }^{1}$, M Obermann $^{1}$ \\ From 4th European Headache and Migraine Trust International Congress: EHMTIC 2014 \\ Copenhagen, Denmark. 18-21 September 2014
}

\section{Introduction}

Vestibular migraine affects $1 \%$ of the general population and $30-50 \%$ of all migraine patients describe occasionally associated vertigo or dizziness.

\section{Aims}

We aimed to identify brain regions altered in vestibular migraine in order to evaluate the connection between migraine and the vestibular system.

\section{Methods}

Seventeen patients with definite vestibular migraine were compared to 17 controls using magnetic resonance imaging based voxel-based-morphometry.

\section{Results}

We found gray matter volume reduction in the superior, inferior and middle (MT/V5) temporal gyrus as well as in the middle cingulate, dorsolateral prefontal, insula, parietal and occipital cortex. A negative correlation of disease duration and GM volume was observed in areas associated with pain and vestibular processing. Moreover, there was a negative correlation between headache severity and prefrontal cortex volume.

\section{Conclusions}

Alterations identified in vestibular migraine resemble those previously described for migraine, but also extent to areas involved in multisensory vestibular control and central vestibular compensation possibly representing the pathoanatomic connection between migraine and the vestibular system.

No conflict of interest.

${ }^{1}$ Neurology, University Hospital Essen, Essen, Germany

Full list of author information is available at the end of the article
Authors' details

${ }^{1}$ Neurology, University Hospital Essen, Essen, Germany. ${ }^{2}$ Diagnostic and Interventional Radiology and Neuroradiology, University Hospital Essen, Essen, Germany.

Published: 18 September 2014

doi:10.1186/1129-2377-15-S1-E42

Cite this article as: Wurthmann et al:: EHMTI-0124. Central vestibular system modulation in vestibular migraine - a VBM study. The Journal of Headache and Pain 2014 15(Suppl 1):E42.

\section{SpringerOpen ${ }^{\circ}$}

(C) 2014 Wurthmann et al; licensee Springer. This is an Open Access article distributed under the terms of the Creative Commons Attribution License (http://creativecommons.org/licenses/by/2.0), which permits unrestricted use, distribution, and reproduction in any medium, provided the original work is properly cited.
Submit your manuscript to a SpringerOpen ${ }^{\circ}$ journal and benefit from:

- Convenient online submission

- Rigorous peer review

- Immediate publication on acceptance

- Open access: articles freely available online

- High visibility within the field

- Retaining the copyright to your article

Submit your next manuscript at $>$ springeropen.com 